\title{
MENUJU REVOLUSI SAINTIFIK MELALUI PENDIDIKAN ISLAM
}

\author{
Asyharul Muala \\ Universitas Islam Indonesia, Yogyakarta \\ Jl. Kaliurang KM 14,5 Yogyakarta \\ E-mail: asyharulmuala@uii.ac.id
}

DOI: $10.29313 /$ tjpi.v6i1.2524

Accepted: May 18th, 2017. Approved: July 20th, 2017. Published: July 20th, 2017

\begin{abstract}
Islamic education, particularly in the form of Islamization of science, does not play a great role to save Muslim generation from backwardness. Therefore, it aims to understand the meaning and range of scientific revolution, to find strategic ways in conducting scientific revolution through Islamic Education, and to have lesson learnt from the best practice of scientific revolution in Islamic world today. Collecting data mainly by library research and employing content analysis, this qualitative research found that the critical process attains scientific revolution to natural sciences. Reflecting the succeed in the West several centuries ago and Iran in contemporary period, this paper formulates that the strategic ways towards scientific revolution are: prefer placing the sacred aspect of science to the goal than to the content, proposing Islamic teaching through scientific formula to the public, and shifting the orientation of education to bear the discoverer and inventor.
\end{abstract}

Keywords: Scientific Revolution, and Islamic Education.

\begin{abstract}
ABSTRAK
Pendidikan Islam terutama yang berformat Islamisasi ilmu pengetahuan belum memberikan hasil yang menggembirakan. Oleh karena itu kajian ini bertujuan untuk memahami pengertian dan ruang lingkup serta metode revolusi saintifik, kemudian menemukan strategi dalam upaya melakukan revolusi saintifik melalui pendidikan Islam, dan untuk mengambil pelajaran dari best practice revolusi saintifik dalam dunia Islam saat ini. Dengan mengumpulkan data melalui studi pustaka kemudian melakukan content analysis, riset bercorak kualitatf ini menemukan bahwa revolusi saintifik dapat dicapai dengan proses kritis terhadap normal science. Berkaca pada keberhasilan Barat selama beberapa abad dan keberhasilan Iran di masa kontemporer, maka strategi pendidikan Islam menuju revolusi saintifik adalah meletakkan sakralitas ilmu bukan pada konten tapi pada fungsi dan tujuan, menyajikan nash Islam dalam bentuk kebenaran ilmiah di depan publik, dan mengubah orientasi pendidikan Islam kepada upaya melabirkan penemu (discovery) dan pencipta (inventor).
\end{abstract}

Kata kunci: Revolusi Saintifik, dan Pendidikan Islam. 


\section{PENDAHULUAN}

Dunia Islam telah lama berada dalam kemerosotan di segala bidang. Salah satunya yang cukup jelas adalah kelemahan dalam hal sains dan teknologi. Hal ini berbanding terbalik dengan dunia Barat yang menjadi kiblat modernitas serta kemajuan dalam banyak hal. Di antara sekian banyak faktor seperti politik, ekonomi, dan budaya, tampaknya faktor pendidikan tetap menjadi aspek penting penentu unggul tidaknya sebuah peradaban. Mundurnya peradaban Islam selama beberapa abad ini tidak lepas dari tumpulnya dunia pendidikan Islam. Pendidikan Islam disadari atau tidak telah lama berada dalam paradigma biner dan dikotomik. Aspek relijiusitas dikembangkan, dimurnikan, diutamakan, karena kesakralannya. Sementara aspek non-relijius ditepikan, dinomorduakan, bahkan dicurigai karena sifat keprofanannya. Hal inilah yang pada akhirnya mengakibatkan semakin mustahil untuk terjadinya sebuah revolusi saintifik di dunia Islam.

Dalam konteks Indonesia, publik justru disibukkan dengan revolusi mental. Sementara revolusi saintifik justru menjadi istilah yang asing bagi sebagian besar publik Indonesia. Padahal revolusi saintifik adalah fakta sejarah yang telah membawa kemajuan besar di abad modern. Mengakui modernitas dan melupakan revolusi saintifik sama saja kacang lupa kulitnya. Ravolusi saintifik membawa kemajuan di banyak bidang kehidupan, hingga akhirnya kalangan muslim pembaharu, yang menggelorakan agenda tajdid dan Islamic revivalism seringkali juga merujuk Barat sebagai indikator keberhasilan dalam sains.

Bagi umat Muslim, menempatkan Barat sebagai acuan dalam pengembangan sains bukan hal yang mudah. Sains Barat lahir dari rahim sekuler; kemajuan Abad Akal dibarengi kemunduran agama (Kristen) di Barat. Oleh karena itu, upaya untuk revolusi saintifik dalam dunia Islam senantiasa terganjal prasangka negatif terhadap keilmuan Barat. Walaupun demikian, kajian sistematis tentang peta hubungan sains dan agama telah muncul sejak awal paruh Ian Barbour sebagai salah satu tokoh pentingnya (Ach. Maemun Syamsudin, 2012: 20-21). Barbour memetakan relasi sains dan agama dalam empat pola yaitu conflict, independent, dialogue, integration. Dalam praktiknya, di dunia Islam kontemporer, upaya menghubungkan sains dan agama dengan pola dialog dan integrasi juga belum lama digaungkan, setidaknya sejak Islamic revivalism menggejala pada abad 19 hingga abad 21 saat ini.

Kemajuan Barat secara bertahap sebenarnya dimulai sejak masa akhir keemasan Islam. Dimulai dari pencerapan keilmuan Islam pada masa skolastik, bergulirnya reformasi gereja, renaissance, revolusi industri, aufklarung (enlightenment) dan seterusnya. Semua proses itu mengantarkan mereka ke abad modern dengan teknologi yang kian canggih. Perkembangan sains di Eropa yang sekuler dan liberal seolah tidak memperlihatkan bekas adanya jasa dan pengaruh Islam bagi kemajuan Eropa.

Islam memiliki peran besar bagi tumbuh kembangnya pemikiran rasional dan keilmuan yang sistematis di Eropa. Pada masa skolastik, banyak orang Eropa yang menimba Ilmu di dunia Islam. Setelah diawali di Madinah pada masa nabi, pengajaran ilmu-ilmu Islam itu berkembang ke daerah lain seperti ke Irak. Awalnya berkembang hanya di dua tempat saja yaitu Basrah dan Kuffah, tetapi setelah didirikan Baghdad sebagai ibu kota, banyak bangsabangsa yang belajar ke kota tersebut. Baru setelah empat kota ini berkembang ke Khurasan (Iran) dan negeri-negeri lain. Pada masa tersebut muncul pula tokoh-tokoh ilmuwan Islam, misalnya dalam bidang agama dikenal seperti Abu Hanifah, Malik, Syafi'i, dan Hanbali dalam bidang hukum Islam. Asy'ari, Al-Maturidi, Wasil bin Ata', Abu Huzail Al-Nazzam dalam bidang teologi. Zunnun Al-Misri, Abu Yazid alBustami dan Al-Halaj dalam Tasawwuf. AlKindi, Al-Farabi, Ibnu Sina, Ibnu Maskawih 
dalam bidang Filsafat. Ibnu Hisyam Ibnu Hayyan, Al-Khawarizmi, Al-Mas'udi, AlRazi dalam bidang ilmu pengetahuan.

Mengingat bahwa Islam pernah mengalami kemajuan dalam sains di satu sisi dan Barat juga telah menjadi pelopor sains modern di sisi lain, maka sebetulnya tidak sulit bagi umat Islam untuk menggulirkan kembali revolusi saintifik. Oleh karena itu, perlu diangkat kembali pemahaman dan semangat revolusi saintifik dan perlu juga ditemukan bagaimana umat Islam harus berupaya mewujudkan agenda tersebut.

Berdasarkan latar belakang masalah dan kegelisahan akademik di atas, maka kajian ini disusun untuk: 1) memahami pengertian dan ruang lingkup serta metode revolusi saintifik, 2) menemukan strategi dalam upaya melakukan revolusi saintifik Islam di era kontemporer terutama melalui dunia pendidikan, 3) dan untuk mengambil pelajaran dari best practice revolusi saintifik dalam dunia Islam saat ini.

Kajian ini diharapkan bermanfaat bagi pengembangan Islamic studies dan isu-isu kontemporer, pengembangan ilmu pendidikan Islam, dan akan memicu lahirnya kembali ilmuwan Muslim yang akan memimpin peradaban.

\section{PEMBAHASAN}

\section{Pengertian Revolusi Saintifik}

Revolusi Saintifik merupakan penanda abad modern. Ciri abad modern adalah pudarnya otoritas (terutama agama), keilmuan yang eskperimental, matematis dan mekanistik (Hooykaas, 1983:22). Oleh karena itu Revolusi Saintifik adalah konsep yang digunakan sejarawan untuk menggambarkan ilmu modern selama periode awal, yakni ketika perkembangan di bidang matematika, fisika, astronomi, biologi dan kimia mengubah pandangan masyarakat tentang alam (Galilei \& Galileo, 1974: 217). Revolusi saintifik terjadi di Eropa pada akhir era renaissance. Pengaruhnya meluas hingga ke gerakan intelektual sosial yang sering disebut pencerahan (enlightenment). Karya Nicolaus Copernicus tahun 1543 De revolutionibus orbium coelestium (On the Revolutions of the Heavenly Spheres) sering dianggap sebagai penanda dimulainya revolusi saintifik.

Revolusi saintifik terjadi di dunia Barat ketika sedang dilanda krisis kehidupan yang cukup berat. Kehidupan ekonomi yang tidak menguntungkan sebagian rakyat jelata dan kehidupan kenegaraan feodalisme yang sangat matrealistis kapitalis menyebabkan gejolak pada bangsa Eropa. Beberapa revolusi terjadi antara lain revolusi Industri, revolusi pertanian, revolusi Perancis, dan revolusi saintifik. Revolusi saintifik merupakan suatu revolusi yang menandakan bangkitnya kelompok intelektual bangsa Eropa mengenai cara berpikir ilmiah. Hal ini termasuk perubahan persepsi manusia dari cara berpikir yang ontologis ke cara berpikir matematis mekanistis.

Tokoh-tokoh pembaharu humanis renaissance seperti Leonardo da Vinci, Michelangelo. N. Copernicus, J. Keppler dan Galileo Galilei sangatlah termashur dengan penemuan dalam bidang ilmu pengetahuan dan karya seni. Ketekunan mereka dalam hal sains mengantarkan Eropa pada Abad aufklaerung (Abad Pencerahan), pada abad 18. Karya penting lain sebagai penanda revolusi saintifik adalah "Philosophiae Naturalis Principia Mathematica" dari Sir Isaac Newton. "Ilmu Pengetahuan Alam berdasarkan prinsipprinsip matematis". Sejak itulah ilmu pengetahuan berkembang pesat dengan pendekatan matematis. Cara berpikir matematis mekanistis dalam revolusi saintifik yang dipelopori oleh Newton menjadi semacam gaya para intelektual untuk membuat analisis dan menghasilkan mesin-mesin teknologi baru yang berkembang pesat.

\section{Proses Terjadinya Revolusi Saintifik}

Gagasan-gagasan ilmiah berkembang pesat, apa yang dipelajari hari 
ini sudah berbeda dengan apa yang menjadi tema sentral lima puluh tahun yang lalu dan akan sangat jauh berbeda dengan satu abad lalu. Dibandingkan cluster keilmuan lain, sains dan teknologi tampaknya merupakan ilmu yang perkembangannya paling cepat. Salah satu tokoh yang memiliki concern dalam laju perkembangan saintifik ini adalah Thomas Kuhn, filsuf dan sejarawan saintifik dari Amerika.

Thomas Samuel Kuhn adalah seorang tokoh yang lahir di Cincinnati, Ohio. Bukunya yang berjudul The Structure of Scientific Revolutions (1963) banyak mengubah persepsi orang tentang apa yang dinamakan ilmu. Buku tersebut juga dicatat oleh The Guardian sebagai salah satu dari 100 buku paling berpengaruh di abad 20. Jika sebagian orang mengatakan pergerakan ilmu itu linier-akumulatif, maka Thomas Kuhn mengatakan, ilmu bergerak melalui tahapantahapan yang akan berpuncak pada kondisi normal dan kemudian krisis karena telah digantikan oleh ilmu atau paradigma baru.

Kuhn mencontohkan beberapa peristiwa revolusi saintifik yang ia maksud, yaitu Copernican revolution dalam astronomi, Einstein revolution dalam fisika, dan Darwinian revolution dalam biologi. Ketiganya menawarkan perubahan fundamental dalam perspektif saintifik. Karena Revolusi saintifik terjadi sangat jarang dalam sejarah, maka Kuhn kemudian membuat tipologi saintifik. Kuhn menamai saintifik yang digunakan sehari-hari dengan sebutan normal science. "The term normal science (is) to describe the ordinary day-to-day activities that scientist engage in when their discipline is not undergoing revolutionary change” (Bagir Zainal Abidin, 2009: 81).

Dalam pandangan Kuhn, normal science adalah sebuah konsep paradigma. Sementara paradigma terdiri dari dua komponen utama yaitu seperangkat asumsi teoretis yang mendasar (fundamental theoretical assumptions) yang secara umum disepakati oleh kalangan ilmuwan, dan seperangkat eksemplar atau masalah ilmiah khusus yang telah dipecahkan dengan asumsi teoretis itu dan yang ada dalam buku-buku disiplin tersebut.

Tugas normal science cukup konservatif. Ia hanya menjaga ilmu atau suatu paradigma tetap lestari. Normal science hanya melakukan perubahan-perubahan kecil atau bersifat minor. Normal science tidak tercipta untuk menguji paradigma. Sebaliknya mereka justru menerima sebuah paradigma tanpa banyak bertanya. Pun jika mereka melakukan riset, tetap hanya dalam batas kerangka paradigmanya sendiri. Sehingga seumpama suatu percobaan menghasilkan temuan yang berseberangan dengan paradigma yang digunakan mau kecenderungannya adalah menyalahkan proses atau teknik yang digunakan, mereka tidak akan menyalahkan paradigma.

Biasanya normal science bertahan bertahun-tahun, bahkan berabad-abad. Selama periode itu para ilmuwan mengoperasikan saintifik, menerapkannya, memperluas cakupannya, dan seterusnya. Semakin lama kemudian ditemukan semacam anomaly, hal yang janggal. Jika kejanggalan itu hanya sedikit maka biasanya dihiraukan. Namun jika semakin intens, berulang kali anomali terjadi, maka yang muncul kemudian adalah krisis. Kepercayaan kepada paradigma lama semakin pudar. Inilah awal terjadinya revolusi saintifik. Orang-orang mulai mengajukan usulan sebuah paradigma baru, dan kemudian sebuah paradigma baru betulbetul terbentuk. Dengan demikian esensi dari revolusi saintifik adalah peralihan dari paradigma lama ke paradigma baru (Bagir Zainal Abidin, 2009: 81).

Revolusi saintifik dalam perpspektif Thomas Kuhn adalah babak perkembangan non-kumulatif, dimana paradigma lama diganti sebagian atau seluruhnya oleh paradigma baru yang bertentangan. Transformasi-transformasi paradigma yang berurutan dari paradigma yang satu ke paradigma yang lainnya melalui revolusi, adalah pola perkembangan yang biasa dari saintifik yang telah matang. Jalan revolusi saintifik menuju normal science bukanlah jalan 
bebas hambatan (Kuhn: 1990). Untuk mengatasi krisis, ilmuwan dapat kembali lagi pada cara-cara ilmiah yang lama sambil memperluas cara-cara itu atau mengembangkan sesuatu paradigma tandingan yang bisa memecahkan masalah dan membimbing riset berikutnya. Jika yang terakhir ini terjadi, maka lahirlah revolusi ilmiah.

Suatu paradigma baru pada saat pertama kali muncul masih sangat terbatas, baik dalam cakupan maupun ketepatannya. Paradigma memperoleh statusnya karena lebih berhasil daripada pesaingnya dalam memecahkan masalah yang pelik. Keberhasilan sebuah paradigma semisal analisis Aristoteles mengenai gerak atau perhitungan Ptolemaeus tentang kedudukan planet, atau yang lainnya. Pada mulanya sebagian besar adalah janji akan keberhasilan yang dapat ditemukan contoh-contoh pilihan dan yang belum lengkap. Hal ini sifatnya masih terbatas serta ketepatannya masih dipertanyakan. Dalam perkembangan selanjutnya, secara dramatis, ketidakberhasilan teori Ptolemaeus betulbetul terungkap ketika muncul paradigma baru dari Copernicus. Oleh karena itu, gagasan Copernicus menjadi sebuah revolusi saintifik.

Revolusi saintifik bertujuan menghasilkan penemuan-penemuan baru yang membawa manfaat lebih besar bagi umat manusia. Data anomali berperan besar dalam memunculkan sebuah penemuan baru yang diawali dengan kegiatan ilmiah. Dalam hal ini Kuhn menguraikan dua macam kegiatan ilmiah, puгzle solving dan penemuan paradigma baru (K. Berten S, 2001).

Dalam purzle solving, para ilmuwan membuat percobaan dan mengadakan observasi yang bertujuan untuk memecahkan teka-teki, bukan mencari kebenaran. Meminjam bahasa Mario Biagioli (1998: 3), ini disebut undeconstructed conceptually, bahwa upaya percobaan atau eksperimental menunjukkan bahwa revolusi saintifik bukanlah dekonstruksi yang terkonsep. Bila paradigmanya tidak dapat digunakan untuk memecahkan persoalan penting atau malah mengakibatkan konflik, maka suatu paradigma baru harus diciptakan (Peter L Berger, 1991: 91). Dengan demikian kegiatan ilmiah selanjutnya diarahkan kepada penemuan paradigma baru, dan jika penemuan baru ini berhasil, maka akan terjadi perubahan besar dalam ilmu pengetahuan.

Penemuan baru bukanlah peristiwaperistiwa yang tersaing, melainkan episodeepisode yang diperluas dengan struktur yang berulang secara teratur. Penemuan diawali dengan kesadaran akan anomali, yakni dengan pengakuan bahwa alam dengan suatu cara, telah melanggar pengharapan yang didorong oleh paradigma yang menguasai saintifik yang normal. Kemudian ia berlanjut dengan eksplorasi yang sedikit banyak diperluas pada wilayah anomali. Ia hanya berakhir bila teori atau paradigma itu telah disesuaikan sehingga yang menyimpang itu menjadi sesuai dengan yang diharapkan. Jadi yang jelas, dalam penemuan baru harus ada penyesuaian antara fakta dengan teori yang baru. Selanjutnya, perlu dijelaskan juga bahwa Kuhn membedakan antara discovery dan invention. Discovery adalah penemuan baru sedangkan invention adalah penciptaan baru. Keduanya saling berhubungan erat dalam penemuan ilmiah.

Termasuk dalam bagian yang tidak kalah penting dalam perkembangan revolusi saintifik adalah konteks teistik yang merupakan bagian dari agama. Salah satu faktor penting perkembangan luar biasa sains adalah dukungan teologi atas asumsi filosofis para ilmuwan, pandangan baru atas sejarah sains seperti ini memperlihatkan bahwa agama dan sains tidak selamanya berseberangan sejak awal. Keyakinan akan keteraturan alam adalah salah satu ajaran teologis yang menjadi acuan metode induksi yang menurut Francis Bacon merupakan kunci utama perkembangan sains (Ach. Maemun Syamsudin, 2012: 65). 


\section{Sejarah Sains dalam Islam}

Dalam sejarah Islam, discovery dan invention bukanlah hal yang asing. Sayangnya, hal tersebut hanya terjadi terutama pada satu periode sejarah Islam, yaitu Masa Keemasan Islam sekitar periode Dinasti Abbasiyah di Baghdad. Periode terbesar kemajuan ilmu pengetahuan Islam terjadi pada abad ke-10 dan ke-11 M. Meskipun demikian, dasardasar ilmu pengetahuan sesungguhnya telah diletakkan oleh generasi-generasi sebelumnya, yaitu pada periode awal Dinasti Abbasiyah, terutama di puncak kejayaaannya, yaitu masa khalifah Harun ArRasyid Rahimahullah (786-809 M) dan puteranya al-Ma'mun (813-833 M). Pada masa tersebut peradaban Islam mencapai masa keemasannya. Akademi-akademi yang mirip universitas modern didirikan di Baghdad, Mosul, Basrah, Nishapur, dan Khurasan. Pusat-pusat pendidikan lainnya berkembang dari semenanjung Iberia sampai India barat laut.

Dalam konteks Dinasti Abbasiyah, kekayaan negara banyak dimanfaatkan Harun al-Rasyid untuk keperluan sosial dan pengembangan ilmu. Ia mendirikan rumah sakit, lembaga pendidikan dokter, dan farmasi. Setidaknya sudah terdapat 800 orang dokter kala itu. Kekhalifahan ini berkembang dengan pesat dan menjadikannya sebagai pusat pengetahuan dengan didirikannya perpustakaan yang akan menyuburkan ilmu pengetahuan di masanya. Kemajuan ilmu pengetahuan ditentukan oleh penerjemahan dan asimilasi antara bangsa Arab dengan bangsa-bangsa lain yang lebih dahulu mengalami perkembangan dalam bidang ilmu pengetahuan.

Gerakan terjemahan berlangsung dalam tiga fase. Fase pertama, pada masa khalifah al-Manshur hingga Harun ArRasyid. Pada fase ini yang banyak diterjemahkan adalah karya-karya dalam bidang astronomi dan mantiq (logika). Fase kedua berlangsung mulai masa khalifah alMa'mun hingga tahun $300 \mathrm{H}$. Buku-buku yang banyak diterjemahkan adalah dalam bidang filsafat dan kedokteran. Fase ketiga berlangsung setelah tahun $300 \mathrm{H}$, terutama setelah adanya pembuatan kertas. Bidangbidang ilmu yang diterjemahkan semakin meluas.

Sedangkan asimilasi bangsa Arab dengan bangsa maju lainnya, misalnya, Persia sangat berpengaruh kuat di bidang ilmu pemerintahan, filsafat, dan sastra. Pengaruh India terlihat dalam bidang kedokteran, ilmu matematika dan astronomi. Sedangkan pengaruh Yunani masuk melalui terjemahan-terjemahan dalam banyak bidang ilmu, terutama filsafat. Sumbangan mereka ini menyebabkan dikenalnya filsuf-filsuf besar Yunani. Ilmu geografi, matematika, dan astronomi misalnya Euclid dan Claudius Ptolemy juga dikenal kemudian diperbaiki lagi oleh beberapa tokoh Islam seperti Al-Biruni.

Hasilnya, beberapa inventor Muslim bermunculan di masa keemasan Islam. Untuk menyebut sebagian saja, misalnya, AlBattani (sekitar 858-929) juga dikenal sebagai Albatenius adalah seorang ahli astronomi dan matematikawan dari Arab. Salah satu pencapaiannya yang terkenal dalam astronomi adalah tentang penentuan Tahun Matahari sebagai 365 hari, 5 jam, 46 menit dan 24 detik. Al-Battani juga menemukan sejumlah persamaan trigonometri, termasuk sin cos tangent. Contoh lain adalah Ibnu Sina. Ia adalah Bapak Pengobatan Modern. Karyanya yang sangat terkenal Al-Qanun fi At Tibb yang merupakan rujukan di bidang kedokteran selama berabad-abad. Ada pula, Muhammad bin Mūsā al-Khawārizmī adalah seorang ahli matematika, astronomi, astrologi, dan geografi yang berasal dari Persia. Buku pertamanya, Al-Jabar adalah buku pertama yang membahas solusi sistematik dari linear dan notasi kuadrat, sehingga ia disebut sebagai Bapak Aljabar. Kata logarisme dan logaritma diambil dari kata Algorismi, Latinisasi dari nama al-Khawārizmī. Tradisi Saintifik Islam di masa Klasik mula merosot pada abad ke-12 dan ke-13. Walaupun sebenarnya masih terdapat juga ilmuwan dan 
karya bermunculan seperti Ibn al-Shatir (1304-1375 M) dari Damsyik dengan kitab falaknya, Ibn al-Nafis dan Serafeddin Sabuncuoglu tentang kitab kedokteran, serta Ibnu Khaldun dan Muqaddimahnya (1370 M) di lapangan ilmu sosial.

Meskipun penemuan-penemuan sudah pernah dicapai oleh Muslim, namun periode itu tidak bertahan hingga kini. Ilmu mulai beralih ke tangan Barat sejak masa Skolastik (abad 9-14 M), dan benar-benar telah dikuasai Barat sejak renaissance (Abad 16). Pasca itu, Islam semakin tertinggal dan menjadi penonton di panggung peradaban sains modern. Oleh karena itu, muncul kerinduan untuk kembali menggenggam sains. Sebagian pemikir muslim kemudian menggelindingkan agenda Islamisasi sains, sebuah pintu masuk yang diharapkan akan membawa Islam kepada revolusi saintifik di abad modern.

\section{Islamisasi Sains: Jalan Menuju Revolusi Saintifik}

Islamisasi ilmu pengetahuan sebetulnya telah lama digaungkan oleh tokoh-tokoh awal dalam gelombang revivalisme Islam (kebangkitan kembali Islam) seperti Jamaluddin Al-Afghani, Muhammad Abduh, Rasyid Ridha, dan seterusnya. Namun sebagai sebuah istilah yang ramai diperbincangkan, Islamisasi ilmu pengetahuan mulai menyeruak sejak Ismail Raji Al-Faruqi mempelopori gerakannya. Kemudian dilanjutkan oleh tokoh-tokoh lain seperti Muhammad Naquib Al-Attas, Abdul Hamid Abu Sulaiman, Sayyed Husein Nasr, Fazlur Rahman, dan Ziauddin Sardar.

Islamisasi ilmu pengetahuan atau Islamiyyat Al-Ma'rifat atau Islamization of Knowledge diakui sebagai sebuah upaya mengembalikan ilmu pengetahuan pada pusatnya yaitu "tauhid". Hal ini dimaksudkan agar ada koherensi antara ilmu pengetahuan dengan iman. Gagasan Islamisasi yang digulirkan al-Faruqi tampaknya dimotivasi oleh kegelisahannya saat melihat ilmu pengetahuan Barat yang semakin sekuler. Menurut Faisal Ismail, kegelisahan Al-Faruqi dipicu salah satunya oleh separasi ilmu-ilmu agama dan ilmu-ilmu sekuler yang sudah lama terjadi yaitu sejak sekularisme dianut oleh masyarakat Barat sekitar abad ke-17 M. Sejak itu hal duniawi (termasuk ilmu pengetahuan umum/sekuler) dibedakan dan dipisahkan dari agama. Di sekolah Barat murid-murid dilarang berdoa di ruang kelas sebelum pelajaran dimulai. Jika pun ada program studi agama (termasuk Islam) di universitas Barat, itu dimaksudkan sebagai kajian akademik murni dan tidak ada kaitannya dengan peningkatan ketakwaan dan penguatan iman. Kemajuan di bidang ilmu dan teknologi kedokteran misalnya banyak "disalahgunakan" untuk praktik aborsi dan euthanasia dalam masyarakat Barat. Berbagai fenomena di Barat itulah tampaknya yang menggerakkan al-Faruqi mencetuskan ide islamisasi ilmu pengetahuan (Ismail, Koran SINDO, 13/2/2015).

Selain itu, Islamisasi ilmu pengetahuan, terutama untuk konteks Asia Tenggara, tidak lepas dari kiprah Muhammad Naquib Al-Attas, pendiri Institute of Islamic Thought and Civilization (ISTAC), Kuala Lumpur, Malaysia. Al-Attas melihat bahwa ilmu pengetahuan yang ada ini tidak bersifat netral, sehingga ilmu pun tidak dapat berdiri bebas nilai (value-free) akan tetapi syarat nilai (value laden) (Muhammad Naquib al-Attas, 1993: 134). Dia berpandangan bahwa ilmu yang ada saat ini sudah terbaratkan atau tersekulerkan. Pengetahuan dan ilmu yang tersebar sampai ke tengah masyarakat dunia, termasuk masyarakat Islam, telah diwarnai corak budaya dan peradaban Barat. Apa yang dirumuskan dan disebarkan adalah pengetahuan yang dituangi dengan watak dan kepribadian peradaban Barat yang jauh dari Wahyu. Karena itu, al-Attas memandang bahwa peradaban Barat tidak layak untuk dikonsumsi sebelum diseleksi terlebih dahulu (Abdullah Ahmad Naim, dkk, 2003: 338). 
Kehidupan Barat yang sekuler telah menjadikan saintifik (ilmu pengetahuan) sebagai satu-satunya pengetahuan yang bersifat otentik yang hanya dikaitkan dengan fenomena semata. Kriteria untuk mengukur sebuah kebenaran juga hanya berpatokan pada rasio. Pandangan seperti itu muncul karena saintifik Barat tidak dibangun di atas wahyu. Namun dibangun di atas budaya yang diperkuat oleh spekulasi filosofis kehidupan sekuler yang memusatkan manusia sebagai makhluk rasional. Akibatnya, ilmu pengetahuan, nilai-nilai etika dan moral, yang diatur oleh rasio manusia, terus menerus berubah. Inilah yang dikritisi oleh Al-Attas.

Pandangan tersebut menurutnya tidak sesuai dengan epistimologi Islam. Menurut al-Attas, pengetahuan Barat telah membawa kebingungan (confusion) dan skeptisisme (skepticism). Menurut Al-Attas, Peradaban Barat juga memandang keraguraguan sebagai suatu sarana epistimologis yang cukup baik dan istimewa untuk mengejar kebenaran (Al-Attas, 1981: 195).

Dikotomi antara saintifik Barat dan Islam tidak mungkin diselaraskan karena terbentuk dari ide-ide, nilai-nilai, kebudayaan, keyakinan, filsafat, agama, doktrin, dan teologi yang bertentangan (Muhammad Naquib Al-Attas, 1981: 197). Pandangan hidup dalam Islam, menurut alAttas, adalah visi mengenai realitas dan kebenaran (the vision of reality and turth). Realitas dan kebenaran dipahami dengan metode yang menyatukan (taubid). Pandangan hidup Islam bersumber kepada wahyu yang didukung oleh akal dan intuisi. Substansi agama seperti keimanan dan pengalamannya, ibadahnya, doktrinnya serta sistem teologinya telah ada dalam wahyu dan dijelaskan oleh Nabi (Armas Adnin, 2005: 14). Dengan demikian, sangat jauh berbeda antara pandangan hidup (world view) yang dibawa oleh Barat dari nilai-nilai keislaman (al-qiyam al-islamiyab). Karena Barat mendasarkan segala sesuatunya dengan kecenderungan pada dikotomisme sedangkan Islam pada konsep tauhid. Dari sanalah kemudian al-Attas mencoba untuk menggagas sebuah konsep Islamisasi yang diharapkan dari konsep ini akan mengcounter peradaban Barat yang sekuler (Muhammad Naquib Al-Attas, 1981: 21).

Meskipun memiliki ghirah yang tinggi dalam menyatukan antara keilmuan dan keislaman, baik Ismail Raji al-faruqi dan Muhammad Naquib Al-Attas tampaknya masih terjebak pada dikotomi ilmu. Terutama dengan argumen historis yang menempatkan keilmuan Barat sebagai ilmu yang sama sekali tidak tersinari wahyu dan seolah-olah muncul tanpa campur tangan Ilahi. Hal inilah yang nantinya sedikit banyak akan dijawab oleh paradigma lain yaitu pengilmuan Islam.

\section{Saintifikasi Islam: Selangkah Menuju Revolusi Saintifik}

Pada dasarnya Islamisasi ilmu pengetahuan yang digelindingkan Al-Faruqi dan Al-Attas dengan Pengilmuan Islam yang digaungkan oleh Kuntowijoyo memiliki persamaan fundamental, yaitu semangatnya untuk mengembalikan ilmu kepada muara tauhid. Dalam gagasan Kuntowijoyo, tauhid dipandang sebagai innate structuring capacity karena mempunyai kekuatan membentuk struktur yang paling dalam. Sesudah itu ada deep structure yang meliputi akidah, akhlak, syariah dan muamalah baru kemudian halhal permukaan yang tampak dalam perilaku sehari-hari (Kuntowijoyo, 2006: 33).

Meskipun landasannya serupa, namun metode yang digunakan cukup berbeda. Metode yang digunakan Kuntowijoyo meliputi dua gerakan utama, yaitu integralisasi dan objektifikasi. Integralisasi ialah pengintegrasian kekayaan keilmuan manusia dengan wahyu (al-Qur'an plus As-Sunnah) sedangkan objektfikasi adalah menjadikan pengilmuan Islam sebagai rabmatan lil 'alamin.

Dengan metode integralisasi Kuntowijoyo ingin menegaskan bahwa sumber keilmuan itu tidak hanya dari rasio manusia (antroposentris) sebagaimana 
diprioritaskan dalam sejarah keilmuan Barat atau sumber wahyu tuhan (teosentris) sebagaimana dibela oleh agamawan, namun harus keduanya. Oleh karena itu, ilmu harus bersumber dari "teoantroposentrisme".

Dengan

landasan

teoantroposentrisme, maka ilmu semestinya bergerak rujuk kembali atau dalam bahasa Kuntowijoyo disebut dediferensiasi. Hal ini penting sebab pada mulanya, terutama dalam sejarah Keemasan Islam, Ilmu dan Wahyu adalah satu kesatuan. Bahkan ketika keilmuan ditransfer dari Timur ke Barat, tranferensi tersebut masih dalam bentuk ilmu yang utuh menyatu. Menurut Hasan Hanafi tardisi Islam diboyong ke Barat ketika masih belum terjadi pemisahan yang jelas antara ilmu-ilmu yang ada dan ketika ilmu kalam, filsafat, tasawuf, ilmu alam, matematika, dan ilmu humaniora masih1. bercampur (Hasan Hanafi, 1999: 243). Baru kemudian, pada akhir masa skolastik hingga2. munculnya masa Renaissance membuat keilmuan tersebut kian terpisah hingga terbentuk dikotomi yang masih terwarisi hingga saat ini. Oleh karena itu, dediferensiasi menghendaki keilmuan itu kembali rujuk dari perceraian yang panjang. Hanya dengan cara inilah akan terjadi integralisasi.

Memang terdapat kemiripan integralisasi dan islamisasi ilmu pengetahuan yang memiliki kehendak yang sama dalam hal mempertemukan dua tradisi ilmu, sehingga gelombang ini sama-sama mengada tanpa terlalu terbedakan. Yang nantinya akan membedakan adalah tahap berikutnya yang ternyata hanya dimiliki oleh Pengilmuan Islam dan belum ditegaskan oleh Islamisasi Pengetahuan. Tahap lanjut yang dimaksud adalah Objektifikasi.

Objektifikasi diperlukan karena integralisasi saja tidaklah cukup. Integralisasi yang bertujuan menyatukan akal dan wahyu pada akhirnya harus berkembang menjadi integralisme, yaitu menyatunya manusia dan agama. Hal tersebut, menurut Kuntowijoyo hanya bisa terjadi jika dilakukan objektifikasi. Secara definitif, objektifikasi adalah penerjemahan nilai-nilai internal ke dalam kategori-kategori objektif (Kuntowijoyo, 2006: 61). Maksudnya adalah upaya membawa nilai-nilai Islam melalui pembawaan yang ilmiah sehingga bisa diterima secara wajar oleh umat lain (nonmuslim) tanpa memandangnya sebagai perilaku keagamaan, sedangkan pelakunya (muslim) masih tetap bisa memandangnya sebagai perilaku agama. Dengan perkataan lain, dalam ranah keilmuan dan sosial, sebenarnya keislaman tidak harus ditunjukkan dengan simbol-simbol dan bahasa-bahasa agama, namun bisa ditebarkan dengan bahasa yang netral digunakan oleh semua orang. Yang paling penting adalah mentransfer nilai-nilainya atau intinya, bukan memasarkan kulitnya.

\section{Iran sebagai Pioner Revolusi Saintifik Islam Modern}

Lembaran sejarah Iran dipenuhi berbagai prestasi para ilmuwannya. Bahkan para sejarawan dunia menyebut sejarah ilmu pengetahuan berutang jasa kepada para ilmuwan Iran. Perhatian yang tinggi terhadap ilmu pengetahuan terus lestari hingga kini. Pasca kemenangan revolusi Islam Iran, salah satu yang menjadi fokus pemangku kebijakan di negara ini adalah masalah perkembangan ilmu pengetahuan dan teknologi.

Salah satu contohnya di bidang medis. Iran mencatat prestasi gemilang berhasil memproduksi obat-obatan dengan formulasi baru, perkembangan di bidang teknik bedah khusus, penemuan mekanisme pengobatan baru, pemberantasan sejumlah penyakit, peningkatan kondisi kesehatan, pembangunan dan perluasan pusat-pusat riset ilmiah yang diperlukan masyarakat khususnya di bidang rekayasa medis. Demikian juga dengan nano teknologi, stemsel hingga teknologi nuklir. Semua itu tidak bisa dilepaskan dari pesatnya produksi ilmu pengetahuan di negara ini.

Posisi ilmiah Iran dalam 18 tahun terakhir melesat naik dengan cepat. Iran 
pada tahun 1998 berada di posisi 52 dalam produksi paper ilmiah. Namun tahun lalu, Iran menyaksikan peningkatan besar produksi karya ilmiah oleh para ilmuwan Iran di berbagai jurnal ilmiah ternama dunia. Indeks perkembangan sains mencakup produksi karya ilmiah, jumlah paper, publikasi, SDM spesialis, para mahasiswa pascasarjana dan doktoral serta posdoktoral, pusat-pusat riset dan universitas yang masuk kategori infrastruktur sains di Iran. Dari semua indeks tersebut, Iran mencatat perkembangan sangat pesat. Berdasarkan proyeksi Republik Islam Iran hingga tahun 1404 H (2025).

Kini, Iran menempati posisi yang baik di tingkat dunia dari aspek produksi ilmu pengetahuan. Iran menempati posisi kedua dari sisi kekuatan ilmiahnya di antara negara-negara anggota Gerakan Non-Blok (GNB). Selain itu selama beberapa tahun3. secara berturut-turut menjadi negara4. terdepan dari sisi perkembangan ilmu pengetahuan di kalangan negara-negara anggota OPEC. Iran menempati posisi pertama produksi sains di negara-negara Timur Tengah dan juga posisi pertama di antara 57 negara Muslim, serta peringkat utama di kawasan dan dunia Islam.

Perbandingan jumlah paper dari Iran yang masuk tahun 2014 dan 2015 di dibandingkan dengan negara lain di dunia menunjukkan pertumbuhan kuantitas produksi ilmu pengetahuan sebesar 8 persen. Iran menempati peringkat ketiga dengan pertumbuhan produksi sains sebesar 13,9 persen, sedangkan di peringkat pertama dan kedua ditempati oleh Rusia dan Australia. Selisih perbedaan Iran dengan Australia sebesar 8 persen, dan selisih dengan Rusia di bidang ini sebesar 3,8 persen.

Kuantitas dan jumlah produksi ilmu pengetahuan kebanyakan negara dunia di tahun 2014 dan 2015 menunjukkan terjadinya penurunan total. Tapi Iran berhasil memproduksi satu persen paper berbobot dunia dengan pertumbuhan 19 persen. Negara ini juga masuk 10 besar negara produsen paper terbaik di dunia dengan pertumbuhan 66 persen.

Selama satu dekade terakhir menunjukkan hanya 25 negara yang memproduksi 84 persen sains dunia. Dari jumlah tersebut, Republik Islam Iran termasuk di dalamnya. Iran menempati posisi pertama dari prosentasi pertumbuhan produksi sains di tahun 2015 sebesar 19 persen. Dari tahun 1990 hingga 2015, produksi ilmu pengetahuan di dunia sebesar 41.920.541 dokumen. Tapi, tidak semua paper dicetak, sebab sebagian paper di jurnal terkemuka secara online bisa diakses secara luas. Republik Islam Iran di tahun 2014 memproduksi 191 paper berbobot. Setahun kemudian, menjadi 227 paper dan menempati satu persen paper terbaik di dunia.

\section{Formula Iran dalam Revolusi Saintifik}

Rahasia sukses Iran dalam revolusi saintifik adalah 1) mengembangkan agama dan sains bersamaan, tanpa harus digabungkan, 2) dekonstruksi konsep kemajuan, 3) membangun epistemologi ilmu agar manusia aktif dan kreatif, 4) mengindari inferioritas kompleks, 5) menghindari paham keagamaan yang memasung pikiran, 6) dan implementasi spirit filsafat Mulla Sadra.

\section{Pertama, di tengah tergopoh-} gopohnya orang Islam untuk mengintegrasikan agama dan sains, Iran justru berbeda; Iran tidak memadukan keduanya, tapi memajukan keduanya. Bagi Iran, Relasi agama dan sains itu bahasa Filsafat. Bagaimana membangun agama dan sains dalam satu tarikan nafas, bukan dua digabung jadi satu. Konteksnya bagaimana maju secara sains dan agama dalam sebuah negara. Yang punya kepentingan tentunya para saintis dan ulama. Signifikansinya sangat penting relasi itu. Tidak ada ulama di Iran reaksioner terhadap sains. Isu agama dan sains itu konteknya dalam kehidupan modern. Integrasi agama dan sains itu efek konsisten dari pandangan tauhid Islam. 
Maka jika dibicarakan zaman Ibnu Sina tidak relevan karena dia pelaku integrasi. Dunia itu satu (tauhid) bukan terbelah menjadi dunia agama dan dunia sains

Kedua, Iran mendekonstruksi konsep kemajuan. Definisi kemajuan Iran bukan dengan pencapaian ala politik mercusuar dengan pencitraan bangunanbangunan fisik. Iran mendefinisikan maju itu Independen, dengan kepala, otak kita sendiri. Qatar, Uni Emirat Arab tidak bisa dikatakan negara maju, tapi hanyalah negara kaya. Mereka hanya membeli hasil sains, bahkan sekedar mengoperasikan saja mereka tidak mampu, harus membayar orang luar. Akhirnya, meskipun kaya, mereka tetap terhegemoni karena tidak memiliki ilmunya. Bagi Iran, kemajuan itu jika mampu memproduksi sains dan bersikap independen sebagai bangsa. Negara yang maju harus mencetak ilmuwan bukan membeli hasil sains (http://indonesian.irib.ir).

Ketiga, faktor epistemologi turut menentukan revolusi saintifik Iran. Salah6. konsep tentang ilmu, sains dilihat dari produk semata bukan dari prosesnya. Dengan sendirinya jika seseorang suka membaca, tekun meneliti, berpikir rasional, menjaga orisionalitas, maka akhirnya produk konkrit itu tinggal mengikuti. Sebenarnya buku, gagasan, hukum Newton, Filsafat Ibnu Sina adalah produk juga. Ilmu bukan koleksi produk sains saja.

Keempat, perlu menghindari "inferiory complex". Kondisi ini dapat muncul akibat terlalu lama dijajah, penyakit rendah diri, selalu hanya merujuk ke Barat jika ingin maju. Ini adalah bentuk penyakit inferioritas kompleks yang sangat merusak dan menghambat kemajuan.

Kelima, perlu menghindari paham keagamaan yang memasung kreativitas berpikir. Ilmuwan butuh kebebasan ontologis. Jerman Timur dahulu secara politik merupakan negara tiran, tapi sainsnya maju. Sebaliknya, di dunia Islam ada larangan tidak boleh mengubah gigi, tidak boleh operasi kulit wajah, tidak boleh mempertanyakan tentang Tuhan, dan seterusnya. Karena teologinya berisi banyak larangan, maka kreativitas mandeg dan sains tidak berkembang.

Terakhir, faktor yang tidak kalah penting bagi Iran adalah adalah manifestasi filsafat hikmah Mutaaliyah Mulla Sadra. Filsafat ini terutama dilihat spiritnya. Sains itu harus independen, semua bagian dari pengembangan jiwa. Iran diperintah oleh ulama dan Filsuf. Menurut Plato, ada tiga model kepemimpinan negara: negara dipimpin 'manusia kepala' (filsuf), negara dipimpin 'manusia dada' (prajurit: gemar perang), dan negara dipimpin 'manusia kaki' (pedagang: mencari keuntungan materi). Idealnya negara dipimpin manusia kepala. Kalau masyarakat dipimpin hawa nafsu maka hancur. Dalam konteks ini, negara dipimpin oleh filsuf (ulama/wali) itu riil dan aktual di Iran.

\section{Revolusi Pendidikan Islam demi Revolusi Saintifik}

Berdasarkan pemaparan di atas, pendidikan Islam perlu dirumuskan kembali agar sejalan dengan agenda revolusi saintifik. Menurut hemat penulis, terdapat beberapa hal yang perlu dilakukan untuk memperbaiki pendidikan Islam agar mampu menghasilkan generasi muslim yang saintifik.

Pertama, pendidikan Islam harus mampu menempatkan ilmu-ilmu sains dan teknologi sama sakralnya dengan ilmu tafsir, ilmu hadits, dan seterusnya. Sakralitas ilmu perlu dikonstruksi ulang. Kesakralan ilmu tidak terletak pada apa yang dipelajari (dimensi ontologi) tapi terletak apa tujuan dan manfaat dari ilmu itu sendiri (dimensi aksiologi). Jika ilmu berdaya guna bagi kemaslahatan, maka ia bernilai sakral karena akan menghasilkan pahala dan keridhaan Tuhan bagi yang ikhlas mengamalkannya. Tidak dipungkiri lagi bahwa ilmu sains dan teknologi membawa maslahat yang luar biasa bagi alam jika benar penggunaannya. Oleh karena itu, dikotomi ilmu agama dan 
non-agama harus diakhiri, sakralitas ilmu perlu direkonstruksi.

Kedua, ajaran Islam perlu disajikan kepada publik sebagai sesuatu yang ilmiah, bukan doktriner. Nilai-nilai dari al-Qur'an dan hadis sedapat mungkin harus diteorikan terlebih dahulu agar menjadi gagasan yang make sense bagi publik. Ketika sebuah gagasan tersebut masuk akal, maka publik manapun akan dapat menerimanya sebagai sebuah kebenaran. Bahkan ketika kebenaran tersebut disajikan secara ilmiah, maka publik tidak akan merasa diceramahi tapi merasa dicerahkan. Dengan kata lain, gagasan yang ilmiah akan diterima publik lebih luas termasuk mereka yang non-muslim. Mereka akan mengikuti gagasan itu karena bagi mereka juga make sense, meskipun sebenarnya asal muasal gagasan itu dari ajaran Islam. Inilah makna Islam sebagai rahmatan lil 'alamin. Untuk dapat mencapai sasaran yang demikian, dunia pendidikan memegang peranan terbesar.

Ketiga, pendidikan Islam harus mendekonstruksi konsep kemajuan, yaitu pendidikan berorientasi produk, bukan sekedar orientasi skill. Sejauh ini, pendidikan hanyalah lembaga untuk menghasilkan tukang, operator, user. Anak didik diarahkan untuk mampu mengoperasikan mesin, menjalankan perusahaan, atau menjadi juru tertentu. Pendidikan belum banyak menginspirasi peserta didik untuk mencipta yang baru (invention) atau setidaknya menemukan sesuatu yang baru (discovery). Oleh karena itu, perlu ditanamkan pengertian bahwa pendidikan yang maju dan berhasil adalah yang melahirkan para penemu dan pencipta, bukan melahirkan para tukang dan pengguna.

\section{KESIMPULAN}

Berdasarkan pemaparan di atas dapat ditarik beberapa kesimpulan. Pertama, revolusi saintifik adalah konsep yang digunakan sejarawan untuk menggambarkan ilmu modern selama periode awal, yakni ketika perkembangan di bidang matematika, fisika, astronomi, biologi dan kimia mengubah pandangan masyarakat tentang alam. Tercapainya revolusi saintifik melalui tahap yang panjang dari sekedar anomali dalam normal sciences kemudian mengalami penguatan dan bergerak menjadi revolusi. Oleh karena itu, revolusi saintifik sebetulnya memang harus dipicu lalu digerakkan, bukan menunggu secara pasif dan membiarkan sains berjalan lambat seperti gerak evolusi.

Kedua, revolusi saintifik pernah terjadi dalam sejarah peradaban Islam, yaitu di periode klasik, tepatnya pada masa Daulah Abbasiyah di Baghdad. Namun keberhasilan dalam sains itu tidak berlanjut ke abad-abad berikutnya, bahkan sebaliknya peradaban Islam mengalami kemerosotan. Oleh karena itu, muncul kerinduan untuk mencapai kejayaan saintifik kembali. Upaya yang dilakukan kemudian adalah dengan Islamisasi sains, sebuah gerakan yang membersamai gelombang Islamic revivalism di berbagai penjuru dunia Islam. Akan tetapi Islamisasi Sains belum cukup, harus ada langkah lebih maju, misalnya dengan saintifikasi Islam. Revolusi sains tidak cukup hanya dengan mengubah baju sekuler barat dengan baju Islam, namun harus mengubah esensi di dalamnya. Ruh dan semangat zaman harus disinari dengan cahaya Islam.

Ketiga, contoh nyata success story revolusi saintifik dalam konteks Islam modern adalah berhasilnya Republik Islam Iran dalam keunggulan sains. Rahasia sukses Iran dalam revolusi saintifik adalah (1) mengembangkan agama dan sains bersamaan, tanpa harus digabungkan, (2) dekonstruksi konsep kemajuan, (3) membangun epistemologi ilmu agar manusia aktif dan kreatif, (4) mengindari inferioritas kompleks, (5) menghindari paham keagamaan yang memasung pikiran, (6) dan implementasi spirit filsafat Mulla Sadra.

Terakhir, pendidikan Islam harus menempuh revolusi demi menghasilkan revolusi saintifik. Cara yang perlu ditempuh di antaranya 1) meletakkan sakralitas ilmu bukan pada konten tapi pada fungsi dan tujuan, sehingga ilmu tidak dikotomis. 2) 
Melalui dunia pendidikan, ajaran Islam harus disajikan sebagai kebenaran ilmiah di depan publik, bukan disajikan sebagai nash doktriner, hal ini agar ajaran Islam menjadi rabmatan lil alamin. 3) pendidikan Islam harus berorientasi pada produk, bukan pada skill saja. Orientasinya adalah melahirkan penemu (discovery) dan pencipta (inventor), bukan hanya melahirkan tukang dan pengguna.

\section{DAFTAR PUSTAKA}

Adnin, Armas. (2005). Westernisasi dan Islamisasi Ilmu, dalam Islamia, Tahun II No. 6 Juli-September 2005.

Al-Attas, Muhammad Naquib. (1981). Islam dan Sekularisme, Terj. Karsidjo Djojosuwarno, Bandung: Pustaka. (1993). Islam and Secularism, Kuala Lumpur: ISTAC.

Bagir, Zainal Abidin. (2009). Religion, Science and Technology, Yogyakarta: Center for Religious and Cross-Cultural Studies UGM.

Berger, Peter L. (1991). Langit Suci Agama sebagai Kreativitas Sosial, Jakarta: LP3S.

Biagioli, Mario. (1998). The Scientific Revolution Is Undead, The Johns Hopkins University Press and the Society for Literature and Science.

Galilei, Galileo. (1974). Two New Sciences, trans. Stillman Drake, Madison: Univ. of Wisconsin Pr.

Hanafi, Hasan. (1999). Oksidentalisme: Sikap Kita terhadap Tradisi Barat, Jakarta: Paramadina.

Hooykaas R.. (1983). A Traditional Narrative of the Scientific Revolution, Seminar Fourth Reunion of the History of Nautical Sciences, Sagres Portugal, 3-8 Juli 1983.

Ismail, Faisal. (2015). Pro-Kontra Islamisasi Imu Pengetabuan, Koran SINDO, Jum'at, 13 Februari 2015.

Khun, Thomas S. (1990). Paradigma Dalam Revolusi Saintifik (The Structure of
Scientific Revolutions), Bandung: Remaja Rosdakarya.

Kuntowijoyo. (2006). Islam sebagai Ilmu: Epistemologi, Metodologi, dan Etika, Yogyakarta: Tiara Wacana.

K. Berten S. (2001). Sejarah Filsafat Yunani; dari Thales ke Aristoteles, Yogyakarta: Kanisius.

Ma'ruf, Muhammad. (2013). Revolusi Islam di Iran Labirkan Revolusi Saintik, (http://indonesian.irib.ir/islam/sor ot/item/68212-Wawancara-

_Revolusi_Islam_di_

Iran_Lahirkan_Revolusi_Saintik). Diakses pada 20 Januari 2017.

Naim, Abdullah Ahmad, dkk. (2003). Pemikiran Islam Kontemporer, Yogyakarta: Jendela.

Syamsudin, Ach. Maemun. (2012). Integrasi Multidimensi Agama dan Sains, Yogyakarta: Ircisod. 